\title{
TWENTY-FIRST CENTURY MALE ELEGANCE AMONGST ELEGANTLY-DRESSING POLISH MALES AND SELF-DECLARED "DANDIES"
}

\section{MĘSKA ELEGANCJA XXI WIEKU WŚRÓD POLSKICH GALANTÓW I DANDYSÓW}

\author{
Grzegorz Maciejewski \\ University of Economics in Katowice, Department of Market and Consumption, \\ 1 Maja Street 47, Build E, 40-287 Katowice, Poland \\ grzegorz.maciejewski@ue.katowice.pl O ORCID: 0000-0002-1318-0747 \\ Dawid Lesznik \\ University of Economics in Katowice, Department of Market and Consumption, \\ 1 Maja Street 47, Build E, 40-287 Katowice, Poland \\ dawid.lesznik@edu.uekat.pl O ORCID : 0000-0002-4298-7013 \\ DOl: 10.2478/minib-2021-0010
}

\section{ABSTRACT}

Dandyism was a thriving philosophical and social movement amongst elegant men of the nineteenth century. The prevailing conviction in the literature on the subject is that the dandy trend began to gradually disappear in the twentieth century, whereas in the new millennium it essentially no longer exists, or at best exists only as a mere shadow of itself. Herein we report a questionnaire study of elegantly-dressing Polish males regarding their behaviour on the fashion market, seeking to gain an better image of this particular market segment and at the same time to identify the features of contemporary dandies and possible connections with the "metro" style. The results indicate that dandyism (at least in the respondents' opinion) is still a lively and thriving e-consumer community, which clearly differs in terms of certain features from metrosexualism. However, the modern-day "dandies" cannot easily be considered heirs to the ideals of their nineteenth-century counterparts. Our findings, in particular the characterization of twenty-first-century elegant-dressing men in Poland, may be of use to fashion brands in the broader men's elegance segment. 


\section{ABSTRAKT}

Dandyzm był kwitnącym ruchem filozoficznym i społecznym wśród eleganckich mężczyzn XIX wieku. W literaturze przedmiotu istnieje przekonanie, że w XX wieku trend dandysa zaczął stopniowo zanikać, podczas gdy w nowym tysiącleciu de facto już go nie ma, a w najlepszym razie istnieje, ale jako cień samego siebie. W badaniach prowadzonych przez autorów wśród polskich mężczyzn preferujących elegancki ubiór, podjęto próbę zbadania ich zachowań na rynku odzieży, aby stworzyć przybliżony obraz segmentu rynku, a jednocześnie zidentyfikować cechy współczesnych dandysów i ich ewentualnych powiązań ze stylem metro. Wyniki wskazują, że dandyzm (przynajmniej w opinii badanych) jest wciąż żywą i dobrze prosperującą społecznością e-konsumentów, która wyraźnie różni się niektórymi cechami od przedstawicieli metroseksualizmu. Jednak współczesnych dandysów nie można uznać za spadkobierców ich XIX-wiecznych ideałów. Wyniki badań, w szczególności cechy galantów XXI wieku, mogą być przydatne dla marek modowych z segmentu męskiej elegancji.

Słowa kluczowe: zachowania konsumentów, rynek odzieży, trend, dandyzm

JEL: D12, M31, Z13

\section{Introduction}

The oldest identified use of the word "dandy" is to be found in the correspondence between two English poets - Lord Byron and Thomas Moor. In a letter dated 25 July 1813, Byron admitted that he himself had been a "dandy" in his youth (Okulicz-Kozaryn 1995, p. 27). At its core, dandyism was not just a distinctive way of truly elegant dressing, especially in the nineteenth century, but a complete philosophical current that elevated elegance and aesthetics in the field of clothing to the status of almost transcendent values, creating a closed club (almost an alternative society) made up of true individualists (Maciejewski and Lesznik 2020, Howells 1996). The dandies, mainly young men (Smith 1974), tried their best to be seen as the most elegant members of society - almost heroes, 
often undertaking an ever-futile and romantic fight against the omnipresent mediocrity. A formally secondary goal (although it is difficult to say if it might not have unofficially been the main one) was to spark interest around oneself, to generate controversy and - above all - to stand out from the crowd (Visser 2011, Rhodes 1928).

The over-elegance of representatives of this trend is considered to be a sign of the Decadent movement, while the dandies themselves are thought to have been guided only by an aesthetic scale (Niedziałkowska 2011). Generally it is believed that dandyism as such constitutes a closed chapter in history - that the trend either died out or evolved in a new direction, losing its fundamentally philosophical traits in favour of simplistic, hedonistic consumption of certain types of luxury goods - for example, stylistically matched sports clothes (Ferrero-Regis 2017). However, dandyism could be reduced to a niche in the clothing market, more broadly within the elegant clothing segment. It has also been suggested that in the twenty-first century this trend may have common points with metrosexuality, and may even potentially constitute the distant source of the latter, as a certain type of seduction strategy (Halligan 2011, Maciejewski 2012, Gheorghe 2015).

The purpose of this study is, therefore, not only to describe the behaviour of elegantly-dressing Polish males (including self-declared "dandies") in a clothing market, but also to juxtapose their characteristics against those of metrosexuals, thus searching for any potential tangential points between these two groups of consumers.

\section{Dandyism in the new era}

The dandies of the nineteenth century can be considered the original "hipsters" who set canons of fashion, while themselves not being subordinate to them (Okulicz-Kozaryn 1995, p. 13). It is difficult to say the same thing about those people who consider themselves dandies today: clearly they do not dictate canons, in fact quite the contrary - they are in some ways opposed to them. Within slightly modernized types showing some connections with dandyism, the authors define in the broadest sense the: the classical, the romantic and the sportive. The "classics" are inspired 
by the golden, nineteenth-century Brummel epoch (a progenitor of all dandies), but adapt their clothes to contemporary reality. They are elegant in the classical sense, somewhat closer to the model of a gentleman, whose clothing is to be a part of the overall image of a person (Przybylski 1982, Skrucha 2012). On the contrary, the "romantics" are characterized by a historical regression of clothes that are matched according to their mood. The most progressive type is "sportive", while its representatives prefer the so-called smart casual (d'Hamilton 2015) - for example a combination of a blazer, jeans and sneakers, which brings to mind the metrosexual style.

Metrosexuals, in turn, are defined as young, wealthy men from large cities who spend a significant part of their income on clothes and improving their self-image (Casanova, Wetzel, and Speice 2016). Because of this characteristic, some authors even classify metrosexuals as narcissistic dandies (Gębala 2008). Metrosexuality does not constitute a life philosophy, rather focusing only on the hedonistic domain of consumption: its individualization (apparent in the postmodern era, Maciejewski 2014) and the so-called well-being (Cheng et al. 2010). However, it is not indicated what style of clothing the expenses are related to. Metrosexualism therefore resembles in some points a reduced form of dandyism, burdened with the casualization of clothing that is characteristic of highly developed postmodern societies of the twenty-first century. On the other hand, it cannot be said that in the new millennium there is a shortage of men interested in classical elegance, as evidenced by the success of blogs (see www 1), internet forums (see www 2) and books devoted to this subject (see Keqdziora 2013). Contemporary elegance on the one hand succumbs to the hedonism of new design, cuttings and fabrics, while on the other, fits into ideas of slow fashion (especially due to the relative stability of classic canons in time, Hirscher 2013) or the broadly understood goals of sustainability of the fashion market - in particular thanks to customers' profound awareness and paying close attention to the quality of the product, which is intended to serve for a longer period of time (Gurova and Morozova 2016).

Some authors, while searching for contemporary elements of dandyism, point to the existing ethnic trends, two of which have been described in depth in the literature: the so-called Muslim dandies and the Swenkas. Muslim dandyism means wearing a suit primarily as a mark of own 
heterosexuality, as well as being a mature man - a serious candidate for a life-time partner to safely build a family with (Khabeer 2017). Therefore, a symbolic significance of clothing serves as an element that builds a man (similarly to classic gentlemen). South African participants of the Swenkas subculture fall slightly more into the characteristic of classical dandyism. So-called swenking is a culture based on a distinctive style and good manners. In essence, following its rules grants prestige and social status. Like the classical type, the Swenkas combine classic with modernity, but without trying to be just another copy of the European style. Swenking can take quite grotesque forms due to the modest living conditions of Swenkers and at the same time their clothes and accessories exorbitantly expensive by local standards (Goeller 2014).

Considering how much dandyism is associated with male elegance, the question arises whether a woman could / can be a dandy. Potentially it might be considered possible, but more likely in terms of the "fashionable woman" - an elegant and well?groomed lady with some features of a dandy. However, it is difficult to identify actual, historical representatives, hence dandyism should be considered a strictly male phenomenon, also today (Gill 2007).

\section{Research methodology and sample description}

After researching secondary sources on the roots and theoretical background of dandyism, we decided to conduct a study using an online survey technique among Polish consumer e?communities gathering together enthusiasts of elegant clothing (hence among a deliberately selected research group), on the assumption that such thematic discussion groups constitute natural communities in which people claiming to be modern dandies might appear.

Due to the difficulty in reaching out to the target group, being a scattered niche, links to our questionnaire were posted on forums and groups devoted to male-elegance enthusiasts, in October and November 2020. This original questionnaire consisted of 21 thematic questions covering a wide spectrum of behaviours and characteristics to describe the 
image of contemporary dandyism, but also the elegant segment of the clothing market - and 7 demographic questions. Respondents could provide their e-mails in order to be sent the published article based on the results of this study - approximately 39\% of the participants expressed interest in the final results. It is estimated that invitations to participate in the study may theoretically have reached a maximum of 7,000 people.

Based on the analysis of the targeted consumer e-communities, it was estimated that the group of men highly interested in elegant style in Poland does not exceed 10,000 in number. Most of them, however, cannot be considered active community participants, hence the number of actual users, deeply interested in the subject, most likely would not exceed 2,000-3,000, of which self-declared "dandies" can be expected to constitute only a fraction (according to the literature, claiming that this is a vanishing trend). A total of 167 completely and correctly completed questionnaires were obtained and were qualified for further analysis, which was carried out using the SPSS 26 statistical package, as well as the WordClouds text visualization and sentiment evaluation software.

The sample as a whole consisted only of men with a median age of 25 years, a mean age of 27.5 and a dominant age of 22 . The respondents may generally be described as relatively young; their characteristics are presented in Table 1.

Due to the relatively young age of the respondents, as many as $67.1 \%$ of them were unmarried. The vast majority of respondents had higher education (64.7\%), whereas less than $1 / 3$ had secondary education. The declared occupations of the participants suggest that most of the interviewees in the latter subgroup were still in course of their highereducation studies. Another tangential point with metrosexuality was found in the size of the respondents' place of residence: $64.1 \%$ of them lived in large cities. However, the distribution of monthly earnings compared to the national average was more uniform: more than half of the respondents had an income equal to or lower than the average wage in the Polish economy. Particular attention should be paid to the percentage of respondents describing themselves as a "dandy" (dandys in Polish), which was slightly 
Table 1. Characteristics of the research sample $(\mathrm{N}=167)$

\begin{tabular}{|c|c|c|c|}
\hline \multirow{2}{*}{\multicolumn{2}{|c|}{ Description }} & \multicolumn{2}{|c|}{ Research sample } \\
\hline & & \multirow{2}{*}{$\begin{array}{c}\text { in numbers } \\
88 \\
79\end{array}$} & \multirow{2}{*}{$\begin{array}{r}\text { in \% } \\
52.7 \\
47.3\end{array}$} \\
\hline Age & $\begin{array}{l}25 \text { or less } \\
26 \text { and more }\end{array}$ & & \\
\hline Marital status & $\begin{array}{l}\text { unmarried } \\
\text { married } \\
\text { divorced } \\
\text { widowed }\end{array}$ & $\begin{array}{r}112 \\
54 \\
1 \\
-\end{array}$ & $\begin{array}{c}67.1 \\
32.3 \\
0.6 \\
-\end{array}$ \\
\hline Education & $\begin{array}{l}\text { primary } \\
\text { vocational } \\
\text { secondary } \\
\text { higher }\end{array}$ & $\begin{array}{c}7 \\
- \\
52 \\
108\end{array}$ & $\begin{array}{c}4.2 \\
- \\
31.1 \\
64.7\end{array}$ \\
\hline Place of residence & $\begin{array}{l}\text { village } \\
\text { town up to } 50 \mathrm{k} \text { inhabitants } \\
\text { town between } 51 \mathrm{k} \text { and } 200 \mathrm{k} \text { inhabitants } \\
\text { town above } 200 \mathrm{k} \text { inhabitants }\end{array}$ & $\begin{array}{r}18 \\
15 \\
27 \\
107\end{array}$ & $\begin{array}{r}10.8 \\
9.0 \\
16.2 \\
64.1\end{array}$ \\
\hline $\begin{array}{l}\text { Monthly earnings relative } \\
\text { to the national average } \\
\text { (September 2020:5372 PLN } \\
\sim 1220 \text { EUR) }\end{array}$ & $\begin{array}{l}\text { significantly below } \\
\text { below } \\
\text { roughly equal } \\
\text { above } \\
\text { significantly above }\end{array}$ & $\begin{array}{l}40 \\
34 \\
18 \\
41 \\
34\end{array}$ & $\begin{array}{l}24.0 \\
20.4 \\
10.8 \\
24.6 \\
20.4\end{array}$ \\
\hline $\begin{array}{l}\text { Form of interest } \\
\text { in an elegant style }\end{array}$ & $\begin{array}{l}\text { non-dandy } \\
\text { dandy }\end{array}$ & $\begin{array}{r}118 \\
49\end{array}$ & $\begin{array}{l}70.7 \\
29.3\end{array}$ \\
\hline
\end{tabular}

Source: Original findings.

less than 30\%: this number stands in stark contrast to the theoretical considerations in the literature, which describe dandyism as fading out at the end of the twentieth century.

Figure 2 presents the professions declared by the respondents in the form of a tag cloud, where the larger the word, the more often it was mentioned in the respondents' answers.

Participants predominantly declared professions traditionally associated with or requiring elegant attire: lawyers, managers, entrepreneurs or economists. There was also a large group of students. 
Fig. 2. Word cloud of respondents' professions

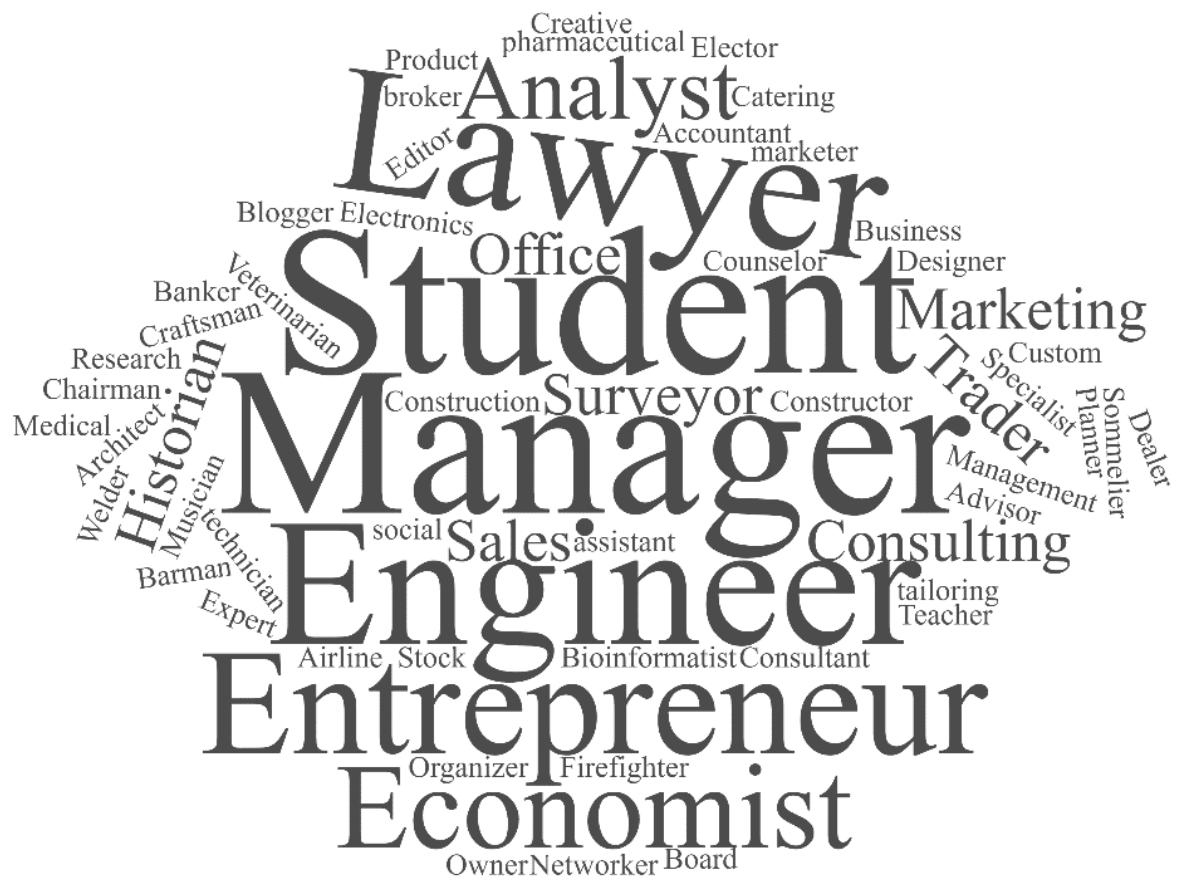

Source: Original findings.

\section{Results}

The broadly-defined elegant style was divided into three currents / subtypes: smart casual (e.g. combining blazers and sneakers), business and strictly formal (the most elegant types of clothing). The respondents' declarations about the preferred sub-types in their own style are presented in Table 2.

Almost $72 \%$ of the respondents generally opted in favour of a more casual style. Among older respondents (26 and over), there was a higher percentage of those choosing a business style, probably for work-related reasons (30.4\% compared to $12.5 \%$ among interviewees aged 25 and under). It is worth noting, however, that younger participants and those from smaller towns relatively more often opted for a formal style as compared to older respondents and those from larger cities. Similar discrepancies were noted in terms of monthly income. A strictly formal style was preferred by $18.4 \%$ of dandies and only $2.5 \%$ of non-dandies. 
Table 2. Respondents' primarily preferred substyles of the elegant style ( $N=167$, in \%)

\begin{tabular}{|c|c|c|c|c|c|c|c|c|c|c|c|}
\hline \multirow{3}{*}{ Description } & \multirow{3}{*}{$\begin{array}{c}\text { Research } \\
\text { sample }\end{array}$} & \multicolumn{10}{|c|}{ Breakdown of respondents by } \\
\hline & & \multicolumn{2}{|c|}{$\underset{\infty}{\infty}$} & \multicolumn{2}{|c|}{ 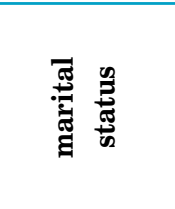 } & \multicolumn{2}{|c|}{ 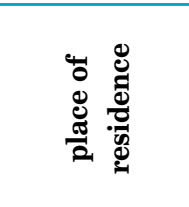 } & \multicolumn{2}{|c|}{ 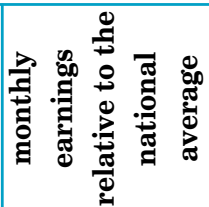 } & \multicolumn{2}{|c|}{ 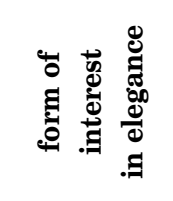 } \\
\hline & & $\begin{array}{l}\text { 今̊ } \\
\text { VI }\end{array}$ & 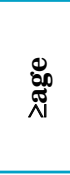 & 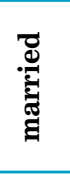 & . & 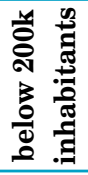 & 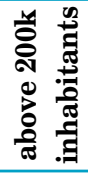 & 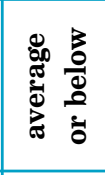 & 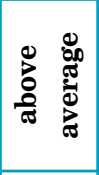 & $\begin{array}{l}\overrightarrow{7} \\
\frac{\pi}{\sigma}\end{array}$ & 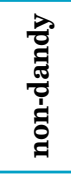 \\
\hline Smart casual & 71.9 & 77.3 & 65.8 & 66.7 & 74.3 & 68.3 & 73.8 & 77.2 & 65.3 & 55.1 & 78.8 \\
\hline Business & 21.0 & 12.5 & 30.4 & 29.6 & 16.8 & 18.3 & 22.4 & 13.0 & 30.7 & 26.5 & 18.6 \\
\hline Formal & 7.2 & 10.2 & 3.8 & 3.7 & 8.8 & 13.3 & 3.7 & 9.8 & 4.0 & 18.4 & 2.5 \\
\hline
\end{tabular}

Source: Original findings.

The reasons as to why the respondents chose a given style were classified into several recurring categories, which are presented in Figure 3.

Fig. 3. Word cloud of respondents' keyword-reasons to choose elegant style ( $N=167)$

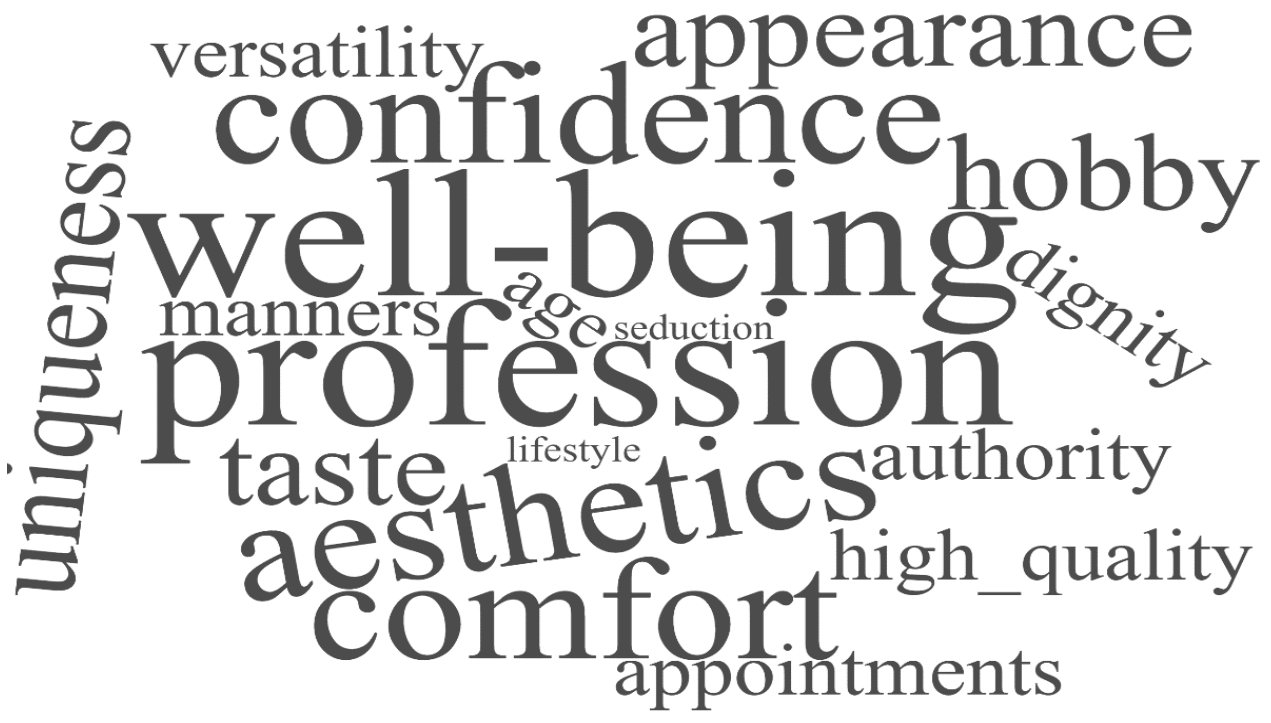

Source: Original findings. 
Interviewees generally indicated well-being and improved self-esteem when they felt they were properly (in that case - elegantly) dressed. Factors also significant were a sense of uniqueness and a desire to stand out from the crowd, as well as an original sense of aesthetics and treating elegant clothing as a hobby - a distinguishing feature of a person. The argument of professional attire was also often cited, even if such requirements were not explicitly stated in respondents' places of work.

A vast majority of respondents (almost 72\%) have been interested in male elegance for at least several years. Only $3 \%$ of participants were just starting their adventure, which indicates that people active in this niche generally have quite "lengthy experience". A detailed breakdown of the respondents is presented in Table 3.

Table 3. Timespans of respondents' interest in elegant style ( $N=167$, in $\%$ )

\begin{tabular}{|c|c|c|c|c|c|c|c|c|c|c|c|}
\hline \multirow{3}{*}{ Description } & \multirow{3}{*}{$\begin{array}{c}\text { Research } \\
\text { sample }\end{array}$} & \multicolumn{10}{|c|}{ Breakdown of respondents by } \\
\hline & & \multicolumn{2}{|c|}{$\underset{\infty}{\infty}$} & \multicolumn{2}{|c|}{ 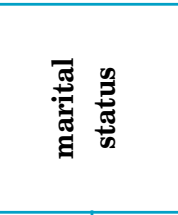 } & \multicolumn{2}{|c|}{ 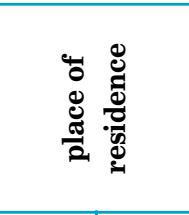 } & \multicolumn{2}{|c|}{ 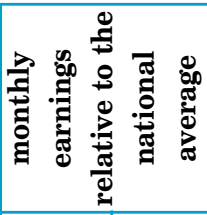 } & \multicolumn{2}{|c|}{ 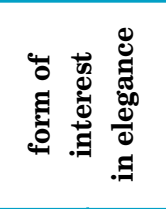 } \\
\hline & & $\begin{array}{l}\text { I̊ } \\
\text { VI }\end{array}$ & 总 & 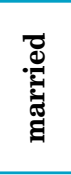 & . & 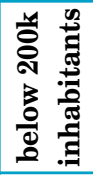 & 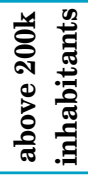 & 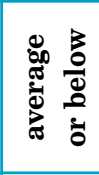 & 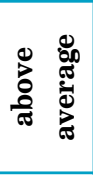 & $\begin{array}{l}\text { 혐 } \\
\text { ్ㅠㅇ }\end{array}$ & 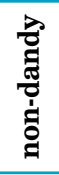 \\
\hline $\begin{array}{l}\text { Less than } \\
\text { a year }\end{array}$ & 3.0 & 4.5 & 1.3 & 1.9 & 3.5 & 3.3 & 2.8 & 3.3 & 2.7 & 2.0 & 3.4 \\
\hline A year or so & 14.4 & 73.9 & 6.3 & 5.6 & 18.6 & 26.7 & 7.5 & 20.7 & 6.7 & 18.4 & 12.7 \\
\hline A few years & 71.9 & 21.6 & 69.6 & 63.0 & 76.1 & 61.7 & 77.6 & 73.4 & 69.3 & 75.5 & 70.3 \\
\hline $\begin{array}{l}\text { Several years } \\
\text { or more }\end{array}$ & 10.8 & - & 22.8 & 29.6 & 1.8 & 8.3 & 12.1 & 2.2 & 21.3 & 4.1 & 13.6 \\
\hline
\end{tabular}

Source: Original findings.

It is not surprising that older respondents generally had a longer history in the field of elegant clothing. This relationship was also observed in terms of marital status, where fewer than $30 \%$ of married respondents had been interested in this subject for several years, analogically in the breakdown based on the level of monthly income. No major differences were found between self-declared dandies vs. non-dandies. 
The main sources of knowledge and inspiration indicated by the respondents are thematic Internet blogs devoted to men's elegance $(88.6 \%$ of respondents declared using them) and discussion groups (70.7\%). Details are presented in Table 4.

\section{Table 4. Respondents' sources of knowledge and inspiration regarding elegant style} $(\mathrm{N}=167$, in $\%$ )

\begin{tabular}{|c|c|c|c|c|c|c|c|c|c|c|c|}
\hline \multirow{3}{*}{ Description } & \multirow{3}{*}{$\begin{array}{c}\text { Research } \\
\text { sample }\end{array}$} & \multicolumn{10}{|c|}{ Breakdown of respondents by } \\
\hline & & \multicolumn{2}{|c|}{$\underset{\infty}{\infty}$} & \multicolumn{2}{|c|}{ 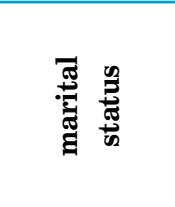 } & \multicolumn{2}{|c|}{ 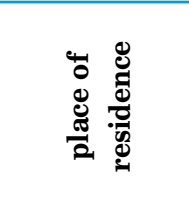 } & \multicolumn{2}{|c|}{ 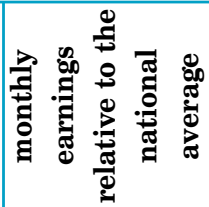 } & \multicolumn{2}{|c|}{ 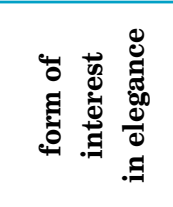 } \\
\hline & & $\begin{array}{l}\stackrel{10}{\text { N }} \\
\text { VI }\end{array}$ & 总 & 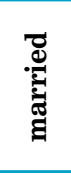 & . & 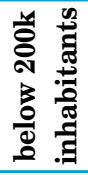 & 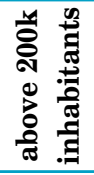 & 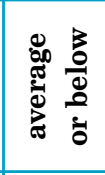 & 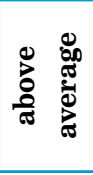 & $\begin{array}{l}\text { 룸 } \\
\text { ్ㅠ }\end{array}$ & 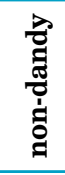 \\
\hline Blogs & 88.6 & 89.6 & 87.3 & 83.3 & 91.2 & 85.0 & 90.7 & 90.2 & 86.7 & 91.8 & 87.3 \\
\hline Online forums & 53.9 & 46.6 & 62.0 & 74.1 & 44.2 & 56.7 & 52.3 & 45.7 & 64.0 & 46.9 & 56.8 \\
\hline $\begin{array}{l}\text { Online } \\
\text { discussion } \\
\text { groups }\end{array}$ & 70.7 & 78.4 & 62.0 & 55.6 & 77.9 & 71.7 & 70.1 & 80.4 & 58.7 & 91.8 & 61.9 \\
\hline Social media & 63.5 & 68.2 & 58.2 & 59.3 & 65.5 & 66.7 & 61.7 & 69.6 & 56.0 & 63.3 & 63.6 \\
\hline $\begin{array}{l}\text { YouTube } \\
\text { channels }\end{array}$ & 61.7 & 73.9 & 48.1 & 42.6 & 70.8 & 68.3 & 57.9 & 77.2 & 42.7 & 73.5 & 56.8 \\
\hline $\begin{array}{l}\text { Traditional } \\
\text { media }\end{array}$ & 30.5 & 23.9 & 38.0 & 37.0 & 27.4 & 33.3 & 29.0 & 28.3 & 33.3 & 32.7 & 29.7 \\
\hline Other** & 3.0 & 2.3 & 3.8 & 5.6 & 1.8 & 3.3 & 2.8 & 2.2 & 4.0 & - & 4.2 \\
\hline
\end{tabular}

* The response percentage does not add up to $100 \%$, as respondents could indicate more than one answer.

** The "other" category includes: personal contacts with friends, tailors and shopkeepers.

Source: Original findings.

Traditional media, including television and literature, are currently the least frequently used source of information about fashion elegance for the respondents, although they are still used by almost one third of participants. The declarations of the respondents were similar in most of the points, but differences emerged as to the use of discussion forums and channels on YouTube. In the case of the younger and unmarried respondents, forums were used only by $46.6 \%$ of them, while for the older 
and married, this percentage was $74 \%$. The reverse relationship occurred in the case of YouTube channels. Online discussion groups are used by more than 9 out of 10 dandies, while amongst non-dandies it is about 3 out of 5 . This supports the claim that that Facebook groups, in particular, may constitute modern dandy clusters.

Although respondents are relatively eager to learn and take inspiration from other participants of e-communities, they are not too eager to actively participate in them themselves. Table 5 contains declarations on the level of activity in discussions on a scale ranging from 1 (does not participate at all) to 5 (participates very actively).

Table 5. Respondents' willingness to participate in discussions on online forums, blogs, social groups, clubs, etc. devoted to elegant style $(N=167)$

\begin{tabular}{|c|c|c|c|c|c|c|c|c|c|c|c|}
\hline \multirow{4}{*}{ Description } & \multirow{4}{*}{$\begin{array}{c}\text { Research } \\
\text { sample }\end{array}$} & \multicolumn{10}{|c|}{ Breakdown of respondents by } \\
\hline & & \multicolumn{2}{|c|}{$\underset{\infty}{\infty}$} & \multicolumn{2}{|c|}{ 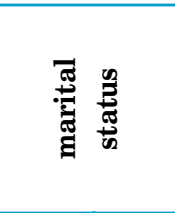 } & \multicolumn{2}{|c|}{ 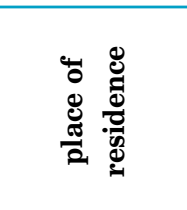 } & \multicolumn{2}{|c|}{ 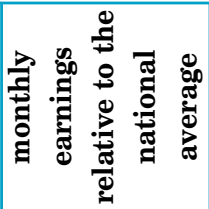 } & \multicolumn{2}{|c|}{ 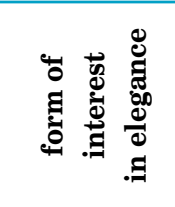 } \\
\hline & & $\begin{array}{l}\text { â } \\
\text { VI }\end{array}$ & : & 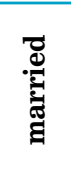 & 噌 & 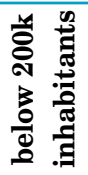 & 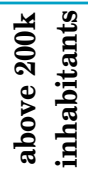 & 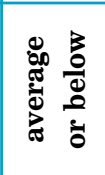 & $\begin{array}{ll}0 & 0 \\
0 & 0 \\
0 & 0 \\
0 & 0 \\
0 & 0 \\
& 0\end{array}$ & 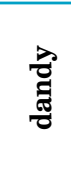 & 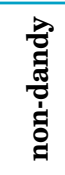 \\
\hline & & \multicolumn{10}{|c|}{ in $\%$} \\
\hline Less than & 3.0 & 4.5 & 1.3 & 1.9 & 3.5 & 3.3 & 2.8 & 3.3 & 2.7 & 2.0 & 3.4 \\
\hline $\begin{array}{l}1 \text { - does not } \\
\text { participate at all }\end{array}$ & 21.6 & 30.7 & 11.4 & 13.0 & 25.7 & 30.0 & 16.8 & 28.3 & 13.3 & 10.2 & 26.3 \\
\hline 2 & 34.7 & 34.1 & 35.4 & 27.8 & 38.1 & 28.3 & 38.3 & 33.7 & 36.0 & 38.8 & 33.1 \\
\hline 3 & 24.6 & 18.2 & 31.6 & 37.0 & 18.6 & 20.0 & 27.1 & 17.4 & 33.3 & 16.3 & 28.0 \\
\hline 4 & 16.2 & 14.8 & 17.7 & 18.5 & 15.0 & 16.7 & 15.9 & 18.5 & 13.3 & 30.6 & 10.2 \\
\hline $\begin{array}{l}5-\text { participate } \\
\text { very actively }\end{array}$ & 3.0 & 2.3 & 3.8 & 3.7 & 2.7 & 5.0 & 1.9 & 2.2 & 4.0 & 4.1 & 2.5 \\
\hline \multicolumn{12}{|c|}{ Selected descriptive statistics } \\
\hline $\bar{M}$ & 2.44 & 2.24 & 2.67 & 2.72 & 2.31 & 2.38 & 2.48 & 2.33 & 2.59 & 2.80 & 2.30 \\
\hline $\mathrm{Me}$ & 2 & 2 & 3 & 3 & 2 & 2 & 2 & 2 & 3 & 3 & 2 \\
\hline Mo & 2 & 2 & 2 & 3 & 2 & 1 & 2 & 2 & 2 & 2 & 2 \\
\hline $\mathrm{SD}$ & 1.09 & 1.11 & 1.02 & 1.04 & 1.09 & 1.22 & 1.01 & 1.14 & 1.02 & 1.12 & 1.05 \\
\hline
\end{tabular}

Where: $\mathrm{M}$ - arithmetic mean, Mo — mode, Me — median, SD — standard deviation.

Source: Original findings. 
At most 8 out of 10 respondents were "moderately active" (answers 1-3). Notably, the older respondents as well as dandies were, on average, more willing to participate in discussions. Among the latter, the share of respondents declaring answers 4 or 5 was almost $35 \%$, while for non-dandies it was around $13 \%$.

On an annual basis, interviewees spend on average EUR 1,173 on elegant clothing, shoes, accessories and other related products, which was roughly close to the average monthly gross national salary in Poland at the time the study was conducted. However, the median salary was notably lower - EUR 682, with the dominant at EUR 455. The breakdown of the statistics is presented in Table 6.

Table 6. Respondents' yearly expenditures on elegant clothes, accessories, shoes, etc. (1 EUR = 4.40 PLN)

\begin{tabular}{|c|c|c|c|c|c|c|c|c|c|c|c|}
\hline \multirow{3}{*}{ Description } & \multirow{3}{*}{$\begin{array}{c}\text { Research } \\
\text { sample }\end{array}$} & \multicolumn{10}{|c|}{ Breakdown of respondents by } \\
\hline & & \multicolumn{2}{|c|}{$\underset{\infty}{\infty}$} & \multicolumn{2}{|c|}{ 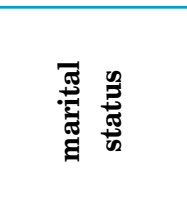 } & \multicolumn{2}{|c|}{ 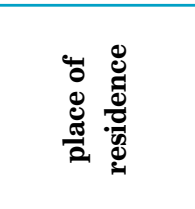 } & \multicolumn{2}{|c|}{ 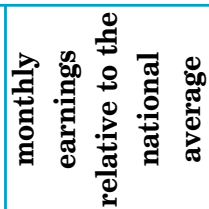 } & \multicolumn{2}{|c|}{ 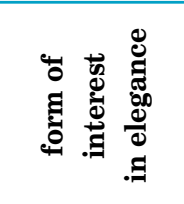 } \\
\hline & & $\begin{array}{l}\stackrel{2}{\text { ô }} \\
\text { v }\end{array}$ & 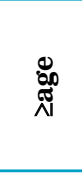 & 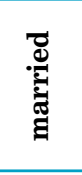 & . & 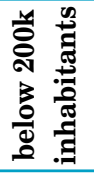 & 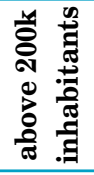 & 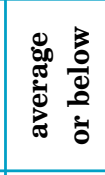 & 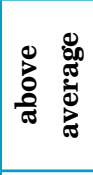 & 륳 & 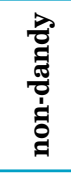 \\
\hline $\mathrm{M}$ & 1173 & 618 & 1792 & 1520 & 1008 & 866 & 1346 & 516 & 1980 & 1183 & 1169 \\
\hline $\mathrm{Me}$ & 682 & 455 & 1136 & 1136 & 455 & 625 & 682 & 455 & 1136 & 682 & 682 \\
\hline Mo & 455 & 455 & 1136 & 1136 & 455 & 682 & 455 & 455 & 1136 & 1136 & 682 \\
\hline SD & 1747 & 672 & 2293 & 1415 & 1869 & 933 & 2052 & 464 & 2321 & 2297 & 1472 \\
\hline
\end{tabular}

Where: $\mathrm{M}$ — arithmetic mean, $\mathrm{Mo}$ - mode, $\mathrm{Me}$ - median, $\mathrm{SD}$ — standard deviation.

Source: Original findings.

Older respondents (with average earnings of EUR 1,792, as compared to EUR 618 for the younger ones) and married respondents could afford to spend more on clothing shopping. The case is similar when it comes to participants from larger cities, but in such a cross-section the dominant for residents of smaller towns was higher (EUR 682 against EUR 455). In general, however, in the sample the determinants of larger sums allocated 
to shopping were: older age, being married, living in a larger city and, naturally speaking, earnings above the average. This image differs in several points from the indicators of metrosexuality proposed in the literature. Given the average and the dominant of spending, there were no major differences between self-declared dandies and non-dandies. For the former, however, the dominant was significantly higher (EUR 1,136 against EUR 682 ) as was the standard deviation (EUR 2,297 against EUR 1,472). Figure 4 shows the box plots of annual expenditures of both of these groups.

Fig 4. Box-plots of dandies' and non-dandies' yearly expenditures on elegant clothes, accessories, shoes, etc., without outliers (1 EUR $=4.40$ PLN)

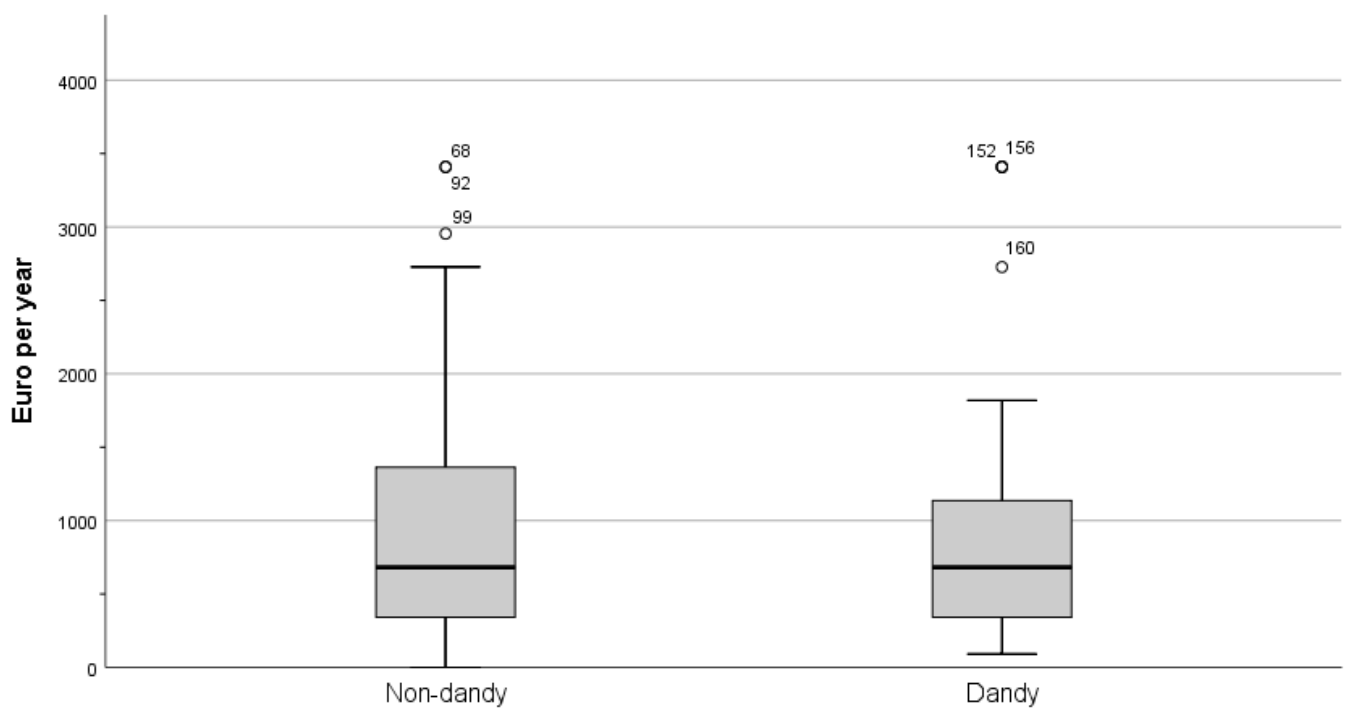

Source: Original findings.

While the first quartile and the median for both dandies and nondandies were more or less equal, the third quartile suggested a certain discrepancy. In the case of the dandies, Q3 was about EUR 1,150, whereas for the rest of the respondents it was around EUR 1,360.

The retail price of the most expensive item in the respondents' wardrobe was on average slightly over EUR 500, with the median of EUR 364. The statistics broken down into research sections are presented in Table 7. 
Table 7. Retail value of the most expensive elegant piece of clothing/shoes/accessories in respondents' wardrobes (1 EUR $=4.40 \mathrm{PLN}$ ).

\begin{tabular}{|c|c|c|c|c|c|c|c|c|c|c|c|}
\hline \multirow{3}{*}{ Description } & \multirow{3}{*}{$\begin{array}{c}\text { Research } \\
\text { sample }\end{array}$} & \multicolumn{10}{|c|}{ Breakdown of respondents by } \\
\hline & & \multicolumn{2}{|c|}{$\underset{\infty}{\infty}$} & \multicolumn{2}{|c|}{ 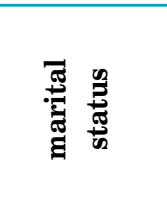 } & \multicolumn{2}{|c|}{ 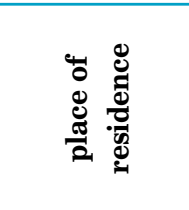 } & \multicolumn{2}{|c|}{ 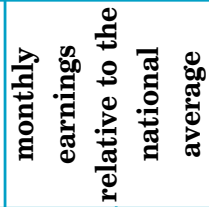 } & \multicolumn{2}{|c|}{ 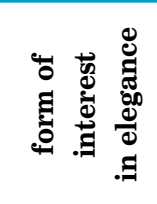 } \\
\hline & & $\begin{array}{l}\text { 今a } \\
\text { VI }\end{array}$ & 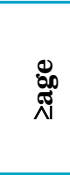 & 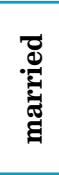 & 兽 & 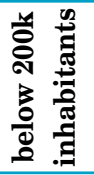 & 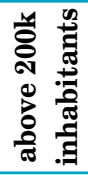 & 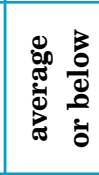 & 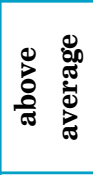 & 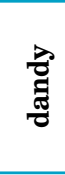 & 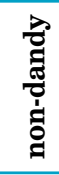 \\
\hline M & 529 & 365 & 712 & 748 & 425 & 511 & 540 & 328 & 776 & 472 & 553 \\
\hline $\mathrm{Me}$ & 364 & 239 & 568 & 625 & 318 & 341 & 386 & 239 & 614 & 318 & 409 \\
\hline Mo & 341 & 341 & 273 & 909 & 341 & 455 & 341 & 341 & 568 & 568 & 341 \\
\hline SD & 508 & 374 & 547 & 528 & 466 & 552 & 484 & 315 & 588 & 562 & 485 \\
\hline
\end{tabular}

Where: $\mathrm{M}$ - arithmetic mean, $\mathrm{Mo}$ - mode, $\mathrm{Me}$ - median, $\mathrm{SD}$ - standard deviation. Source: Original findings.

Older, married and respondents earning above average could afford to buy things about 2 times more expensive than the respondents with the opposite characteristics. The average for dandies was slightly lower than for non-dandies (EUR 472 vs. EUR 553), while the median was similar. In most cases, the most expensive thing in the respondents' wardrobe was a suit (40\% of respondents), for which the average purchase price was around EUR 580. Another $20 \%$ of respondents indicated shoes that cost an average of EUR 366, and $18 \%$ of respondents named a coat worth around EUR 500. Less than $9 \%$ of respondents named a blazer, with an average price of EUR 474.

The respondents were asked to indicate on a 7-point scale how closely in their opinion the currents of dandyism and metrosexuality are related, where 1 meant absolutely no relationship, while 7 - a very close relationship. Table 8 presents the results. 
Table 8. Respondents' views on closeness of connection between dandyism and metrosexualism $(N=167)$

\begin{tabular}{|c|c|c|c|c|c|c|c|c|c|c|c|}
\hline \multirow{4}{*}{ Description } & \multirow{4}{*}{$\begin{array}{c}\text { Research } \\
\text { sample }\end{array}$} & \multicolumn{10}{|c|}{ Breakdown of respondents by } \\
\hline & & \multicolumn{2}{|c|}{$\underset{\infty}{\infty}$} & \multicolumn{2}{|c|}{ 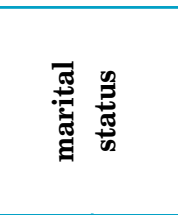 } & \multicolumn{2}{|c|}{ 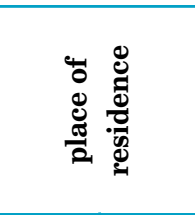 } & \multicolumn{2}{|c|}{ 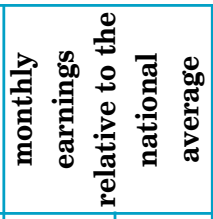 } & \multicolumn{2}{|c|}{ 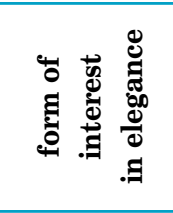 } \\
\hline & & $\begin{array}{l}\text { ลิ } \\
\text { VI }\end{array}$ & 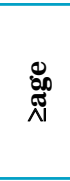 & 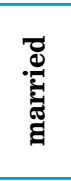 & $\frac{0}{80}$ & 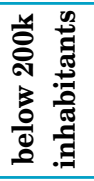 & 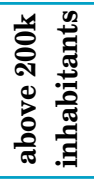 & 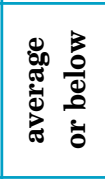 & 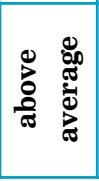 & $\begin{array}{l}\text { 혐 } \\
\text { ్ㅠㅇ }\end{array}$ & 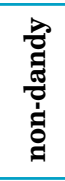 \\
\hline & & \multicolumn{10}{|c|}{ in $\%$} \\
\hline $\begin{array}{l}1-\text { not related } \\
\text { at all }\end{array}$ & 12.0 & 5.7 & 19.0 & 20.4 & 8.0 & 13.3 & 11.2 & 4.3 & 21.3 & 18.4 & 9.3 \\
\hline 2 & 17.4 & 20.5 & 13.9 & 16.7 & 17.7 & 16.7 & 17.8 & 18.5 & 16.0 & 16.3 & 17.8 \\
\hline 3 & 23.4 & 21.6 & 25.3 & 25.9 & 22.1 & 20.0 & 25.2 & 20.7 & 26.7 & 22.4 & 23.7 \\
\hline 4 & 17.4 & 15.9 & 19.0 & 13.0 & 19.5 & 15.0 & 18.7 & 19.6 & 14.7 & 18.4 & 16.9 \\
\hline 5 & 16.2 & 18.2 & 13.9 & 14.8 & 16.8 & 16.7 & 15.9 & 18.5 & 13.3 & 16.3 & 16.1 \\
\hline 6 & 10.2 & 13.6 & 6.3 & 5.6 & 12.4 & 15.0 & 7.5 & 16.3 & 2.7 & 6.1 & 11.9 \\
\hline $\begin{array}{l}7 \text { - closely } \\
\text { related }\end{array}$ & 3.6 & 4.5 & 2.5 & 3.7 & 3.5 & 3.3 & 3.7 & 2.2 & 5.3 & 2.0 & 4.2 \\
\hline \multicolumn{12}{|c|}{ Selected descriptive statistics } \\
\hline$\overline{\mathrm{M}}$ & 3.53 & 3.80 & 3.24 & 3.17 & 3.71 & 3.63 & 3.48 & 3.87 & 3.12 & 3.24 & 3.65 \\
\hline $\mathrm{Me}$ & 3 & 4 & 3 & 3 & 4 & 3.5 & 3 & 4 & 3 & 3 & 3 \\
\hline Mo & 3 & 3 & 3 & 3 & 3 & 3 & 3 & 3 & 3 & 3 & 3 \\
\hline SD & 1.64 & 1.63 & 1.61 & 1.68 & 1.6 & 1.75 & 1.59 & 1.54 & 1.68 & 1.61 & 1.65 \\
\hline
\end{tabular}

Where: $\mathrm{M}$ - arithmetic mean, $\mathrm{Mo}$ - mode, $\mathrm{Me}$ - median, $\mathrm{SD}$ — standard deviation.

Source: Original findings.

The responses were generally quite balanced, but suggested no close relationship: in general more than $70 \%$ of the respondents gave a score of at most 4 on the scale. The average of the declarations was 3.53, with the dominant and the median at the level of 3. A slightly closer relationship was indicated by younger and unmarried respondents, as well as those earning no more than the national average. More affluent respondents more clearly showed no relationship (mean 3.12 vs. 3.87 in the opposite cross-section). Self-declared dandies themselves also claimed to be somewhat more distinct: with an average of 3.24, no more than three-fourths of them gave 
a maximum score of 4 . In the case of non-dandies, these figures were 3.65 and $67.7 \%$ respectively.

When asked to name the determinants or characteristics of a modernday dandy, the respondents most often indicated elegance in clothing and attachment to impeccable appearance. Their responses are visualized in Figure 5 in the form of a word cloud.

Fig. 5. Word cloud of respondents' view of modern-day dandies / dandyism $(\mathrm{N}=167)$

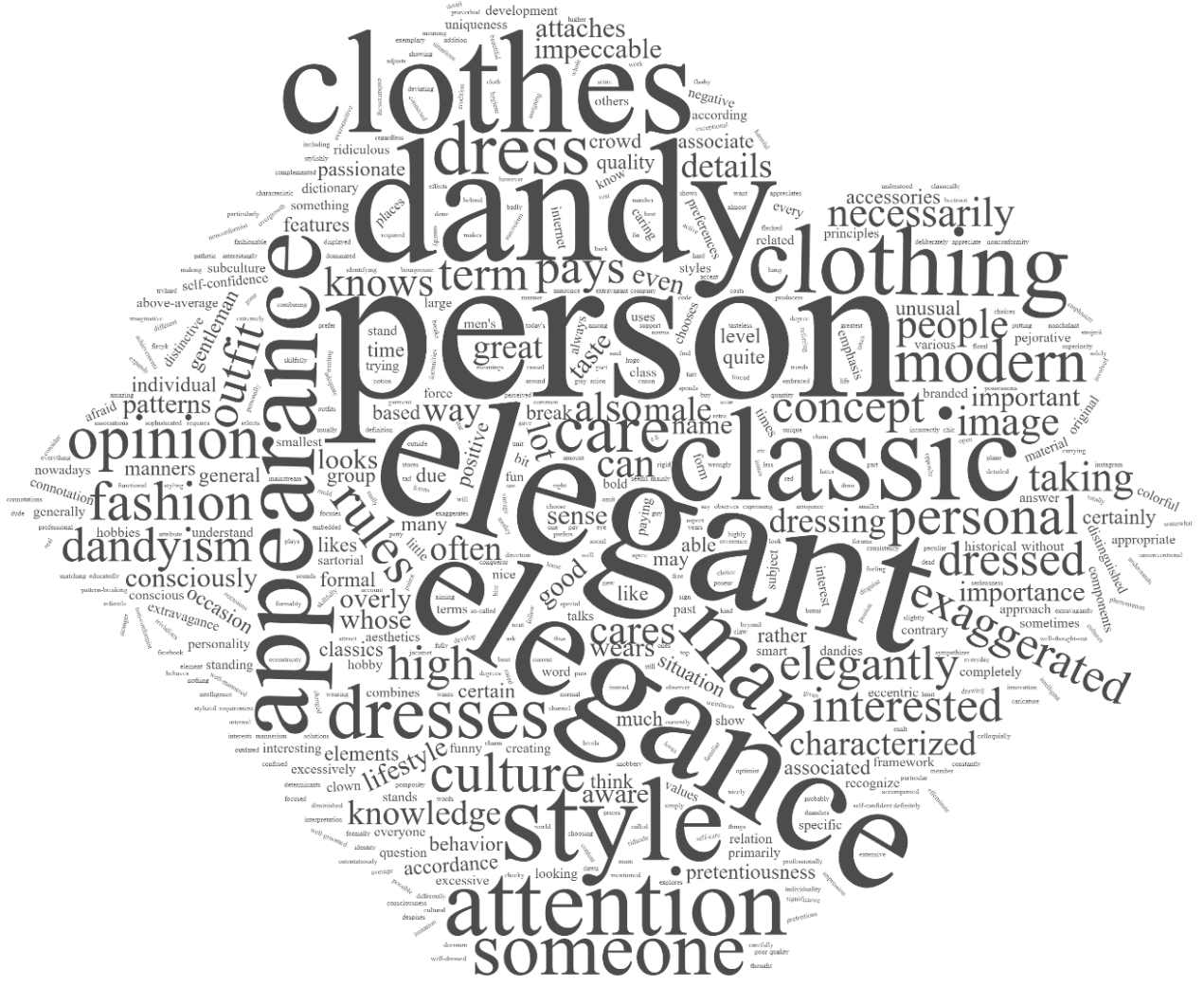

Source: Original findings.

Notably, the responses did not mention at all the aspect of the philosophical foundation with which dandyism was originally associated. Currently, it seems to be solely reduced to an aesthetic domain, just one of many styles of dressing, or a set of certain personality traits. A modernday "dandy" is considered to be a man who dresses to impress and is 
especially fond of classic, elegant clothing. Attention to detail and high quality were also indicated, as well as a tendency to sometimes go a bit overboard (going to the extreme in terms of elegance, being overdressed for the occasion).

\section{Conclusions}

The Polish sympathizers of male elegance whom we surveyed generally proved to be generally young, well-educated and from larger cities. At the same time, they did exhibit significant income stratification. The respondents generally held professional positions that required elegant attire or were still university students (perhaps with aspirations to hold such positions in the future). At the same time, they claimed that their main reasons for choosing an elegant style were their own well?being, their sense of aesthetics and above all - their desire to project a professional self-image at work.

The gallant Polish men we surveyed focus mainly on so-called everyday elegance (smart casual), in which, on average, they generally have several years of dressing "experience". However, there is no shortage of young people just starting out on their adventure with elegant dressing - they obtain the necessary knowledge for such a quest primarily from internet blogs and thematic discussion groups, pointing to the importance of opinion leaders within these e?communities. Despite their eagerness to draw upon the knowledge of others in this way, however, the respondents were not very keen to actively participate in such discussions themselves. Their annual budgets for elegant items of clothing fluctuated around EUR 1,200, which was about equivalent to the national average gross monthly salary in Poland at the time of study. In order to satisfy all their clothing needs, they have to ration their expenses, so that the most expensive items in their wardrobes (most often suits) generally cost around EUR 500.

Despite the fact that dandyism is described in the existing literature as a trend nearly vanished, nearly $30 \%$ of our respondents did indeed describe themselves as "dandies" (dandys in Polish). These participants 
relatively more often preferred business and formal style, as well as more often made use of thematic discussion groups, hence it may be expected that such e-communities are in fact contemporary "meeting places" for dandies. At the same time, self-declared "dandies" were somewhat more keen to participate in discussions there. It cannot be concluded that respondents considering themselves "dandies" had larger budgets for clothes - in fact quite the contrary, some statistics indicated a slightly lower level of their expenses. The self-declared dandies were amongst those most critical of the notion of a possible connection between "dandy" style and metrosexualism. However, the respondents as a whole did not rule out such a connection, indicating some existing similarities. It remains an open question to what extent contemporary dandies may actually be considered heirs to their nineteenth-century ideals, and not just sartorialists gravitating more towards mere hedonism in the domain of elegance.

In general, this study has a number of obvious limitations: above all, it was conducted on a non-representative sample, and thus the results presented should be analysed with caution. Nevertheless, we believe that the findings shed some new light on an under-researched segment of highend men elegant dressing. The authors encourage other researchers to participate in discussion on the subject and undertake further joint research in this area of study.

\section{References}

1. Casanova, E., Wetzel, E., \& Speice T. (2016). Looking at the label: White-collar men and the meanings of "metrosexual". Sexualities, 19(1/2), 64-82. DOI: 10.1177/ 1363460715583607.

2. Cheng, F. S., Ooi, C. S., \& Ting, D. H. (2010). Factors affecting consumption behavior of metrosexual toward male grooming products. International Review of Business Research Papers, 6(1), 574-590.

3. D'Hamilton, C. (2015). Dandyism: Beyond fashion. Greater Bay Area Costumers Guild.

4. Ferrero-Regis, T. (2017). Twenty-first century dandyism: Fancy Lycra ${ }^{\circledR}$ on two wheels. Annals of Leisure Research, 21(1), 95-112. https://doi.org/10.1080/ 11745398.2017.1379028. 
5. Gębala P. (2008). Metroseksualizm: ponowoczesna kultura narcyzmu. Horyzonty Wychowania, 7(13), 93-114.

6. Gheorghe, M. (2015, February 2). From dandyism to metrosexuality: Between context and content. Available at SSRN: https://ssrn.com/abstract=3296528 or http://dx.doi.org/ $10.2139 /$ ssrn.3296528.

7. Gill. M. (2007). The myth of the female dandy. French Studies, LXI(2), 167-181. https://doi.org/10.1093/fs/knm062.

8. Goeller, D. (2016). Portrait of a gentleman - Swenking and the re-actualization of dandyism in South Africa 2014. https://www.researchgate.net/publication/ 305467987_Portrait_of_a_Gentleman_-_Swenking_and_the_Reactualization of_Dandyism_in_South_Africa (accessed: 04.01.2021).

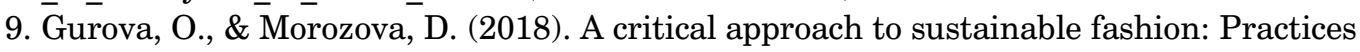
of clothing designers in the Kallio neighborhood of Helsinki. Journal of Consumer Culture, 18(3). First published in 2016. DOI: 10.1177/1469540516668227.

10. Halligan, B. (2011). Metrosexual [in:] Encyclopedia of Consumer Culture. Sage Publications. https://usir.salford.ac.uk/id/eprint/22608/ (accessed: 04.01.2021).

11. Hirscher, Anja-Lisa (2013). Fashion activism evaluation and application of fashion activism strategies to ease transition towards sustainable consumption behaviour. Research Journal of Textile and Apparel, 17(1), 23-38. https://doi.org/10.1108/RJTA-1701-2013-B003.

12. Howells, B. (1996). Baudelaire: Individualism, dandyism and the philosophy of history. Routledge.

13. Legenda: Research Monographs in French Studies. University of Oxford. European Humanities Research Centre.

14. Kędziora, M. (2013). Rzeczowo o modzie męskiej. Poradnik. Wydawnictwo Sine Qua Non, Kraków.

15. Khabeer, S. A. (2017). Muslim dandies. Anthropology News (Special Issue: Fashion), 58(5), 47-54.

16. Maciejewski, G. (2012). The contemporary consumer in the face of megatrends in consumption (Chapter 2). In A. Olejniczuk-Merta (Ed.), The transformation of consumption and consumer behaviour (pp. 27-42). Instytut Badań Rynku, Konsumpcji i Koniunktur. Warsaw

17. Maciejewski, G. (2014). Zachowania konsumentów w dobie postmodernizmu. Marketing i rynek, 8, 1129-1136.

18. Maciejewski, G., \& Lesznik, D. (2020). Dandyism - A new trend on the fashion market or just a blast from the past? The 35th IBIMA Conference, Seville, Spain (April 1-2, 2020). 12(1), 9082-9090.

19. mrvintage.pl (accessed: 04.01.2021)

20. Niedziałkowska, D. (2011). Dandyzm w „Dwóch biegunach” i „Argonautach” Elizy Orzeszkowej. Wiek XIX. Roczniki Towarzystwa Literackiego imienia Adama Mickiewicza, 4(46), 102-120.

21. Okulicz-Kozaryn, R. (1995). Mata historia dandyzmu. Wydawnictwo Obserwator. Poznań 
22. Przybylski, R. (1982). Gentleman i dandys. In M. Janion, \& M. Zielińska (Eds.), Style zachowań romantycznych: propozycje i dyskusje sympozjum Warszawa 6-7 grudnia 1982. Państwowy Instytut Wydawniczy. Warszawa 1986.

23. Rhodes, S. A. (1928). Baudelaire's philosophy of dandyism. The Sewanee Review 1928/10, 36(4), 387-404.

24. Skucha, M. (2012). Męskości nowoczesne? Wiek XIX. WIELOGEOS [Pismo Wydziału Polonistyki UJ], 1(11). Wydawnictwo Uniwersytetu Jagiellońskiego. https://doi.org/ 10.4467/2084395XWI.12.001.0606.

25. Smith, T. S. (1974). Aestheticism and social structure: Style and social network in the dandy life. American Sociological Review, 39(5), 725-743.

26. styleforum.net (accessed: 04.01.2021)

27. Visser, J. (2011). The dandy as an innovator: The usefulness of paradoxes. In Fashion \& luxury: Between heritage \& innovation. [IFFTI 13th annual conference proceedings], 182-186. Institut Français de la Mode, France.

Grzegorz Maciejewski - holds a postdoctoral degree (DSc) in Economic Sciences. He is a Professor at the University of Economics in Katowice, where he is head of the Market and Consumption Department. He manages research projects at the Centre for Knowledge Research and Development in Katowice and the manager and contractor of six grants from the Polish Ministry of Science and Higher Education. An academic tutor and mentor, his scientific interests are mainly in the area of behavioural economics. He is the author of over 140 articles in the fields of consumer behaviour, the marketing strategies of enterprises and market and marketing research methodologies. A member of the Polish Society of Market and Opinion Researchers (PTBRiO), the Polish Scientific Marketing Society and the PGV International Scientific Network.

Dawid Lesznik - is a staff member of the Market and Consumption Department at the University of Economics in Katowice. Out of a passion for financial markets, he works as a stock market analyst. His scientific interests include behavioural economics, stock market psychology as well as monetary policy. He is interested in the practical implications of technical analysis and the impact of macroeconomic indicators on financial markets. His great passions also include the fashion markets, paying particular attention to the purchasing behaviours of individual consumers. 